UDC 628.169.7 + 666.9

DOI: https://doi.org/10.20535/2218-93002522019187942

\title{
ARSENIC-CONTAINING WASTES OF WATER TREATMENT: POSSIBLE WAYS OF UTILIZATION
}

\section{Litynska, A. Gusak, N. Tolstopalova, I. Astrelin}

National Technical University of Ukraine "Igor Sikorsky Kyiv Polytechnic Institute”, Kyiv, Ukraine, m.litynska-2017@kpi.ua

Article history:

Received: 4 October 2019

Accepted: 21 November 2019

Print: 20 December 2019
Iron (III) arsenate and some other arsenates have a much lower solubility in an alkaline environment, that is, it is advisable to store and use these wastes together with compounds that provide an alkaline reaction. Cement is characterized by high $\mathrm{pH}$ values, and the content of arsenic in cement is not normalized, because the human body does not directly contact with cement. The experimental results proved that utilization of arsenic-containing adsorbents in the form of concrete products was safe in case of arsenic content from 53.3-142.2 $\mu \mathrm{g} / \mathrm{g}$ and had perspectives in colouring of concrete products.

Key words: arsenate; arsenic compounds; cement; concrete; utilization of adsorbents.

1. Introduction

Pure drinking water is very important for all organisms and especially for humans. But natural waters of many countries have insufficient quality and are unsafe for drinking. Safe drinking water for all is one of the main goals of modern society.

Arsenic is one of toxic components, which is often present in natural water, especially in groundwater and artesian water. Arsenic-containing minerals and rocks are the main source of arsenic. So, leaching from minerals is the main pathway of arsenic pollution of groundwater and artesian water (Berg, 2007).

Figure 1 demonstrates map of possible arsenic pollution of natural water.

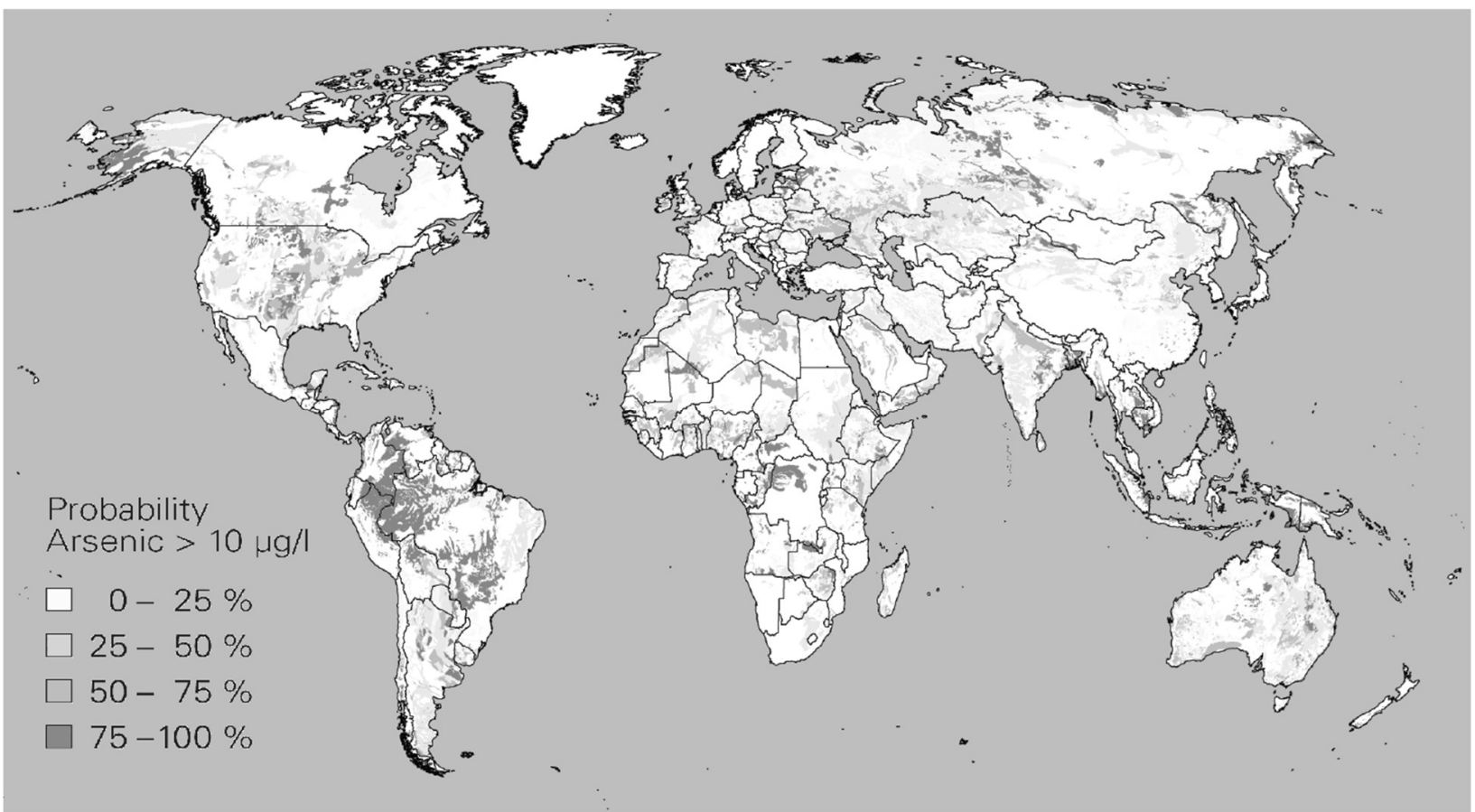


Figure 1. Probability of arsenic content higher than $10 \mu \mathrm{g} / \mathrm{L}$ in natural water (Amini et al., 2008).

Maximum allowable concentration of arsenic is $10 \mu \mathrm{g} / \mathrm{L}$, but a lot of natural water has significantly higher arsenic content. Arsenic-containing natural water is very big problem in such regions as Kurdistan (Iran), where the concentration of arsenic in some natural waters reaches 1480 $\mu \mathrm{g} / \mathrm{L}$ (Mosaferi et al., 2003); Antafahasta (Chile), where the level of arsenic can reach $860 \mu \mathrm{g} / \mathrm{L}$ (Steinmaus et al., 2014); Xinjiang Province (China), where the level of arsenic in the groundwater is $1200 \mu \mathrm{g} / \mathrm{L}$; Rehe and Ruihai region (China), where alkaline thermal water of hot springs contains arsenic in the range 83-687000 $\mu \mathrm{g} / \mathrm{L}$ (He and Charlet, 2013). Groundwater and artesian water with high arsenic concentration are typical for Hungary, Bangladesh, China, India, Taiwan, Vietnam, USA, Mexico, Chile, Argentina, Ghana, etc. (Berg, 2007).

High arsenic content (higher than $10 \mu \mathrm{g} / \mathrm{L}$ ) in drinking water provokes a lot of different diseases and disorders. Properties of $\mathrm{As}(\mathrm{V})$ are similar to the $\mathrm{P}(\mathrm{V})$ properties, so $\mathrm{As}(\mathrm{V})$ take the place of phosphorus in biochemical processes. But $\mathrm{As}(\mathrm{V})$ is not completely same with $\mathrm{P}(\mathrm{V})$ due to its atom radius, so this replacement leads to different failures in biochemical reactions and as the result failures in functioning of organs and glands (Magellan et al., 2014). As(III) has another mechanism of action and its toxicity is higher. Cancer, endocrine disruption, neurological disorders, genotoxic effects are among the results of arsenic-containing water.

Thus, treatment of arsenic-containing natural waters is very important for population health.

But arsenic-containing wastes of water treatment are produces not only at drinking water treatment plants. Some industrial wastewaters also contain a lot of arsenic.

As a result of the purification of such natural and waste waters, numerous arsenic-containing wastes are obtained, which can be conditionally divided into two groups - solid (coagulation sediment, spent adsorbents) and liquid (solutions for regeneration of ion exchange resins and sorbents, concentrates from reverse osmosis) (Figure 2).

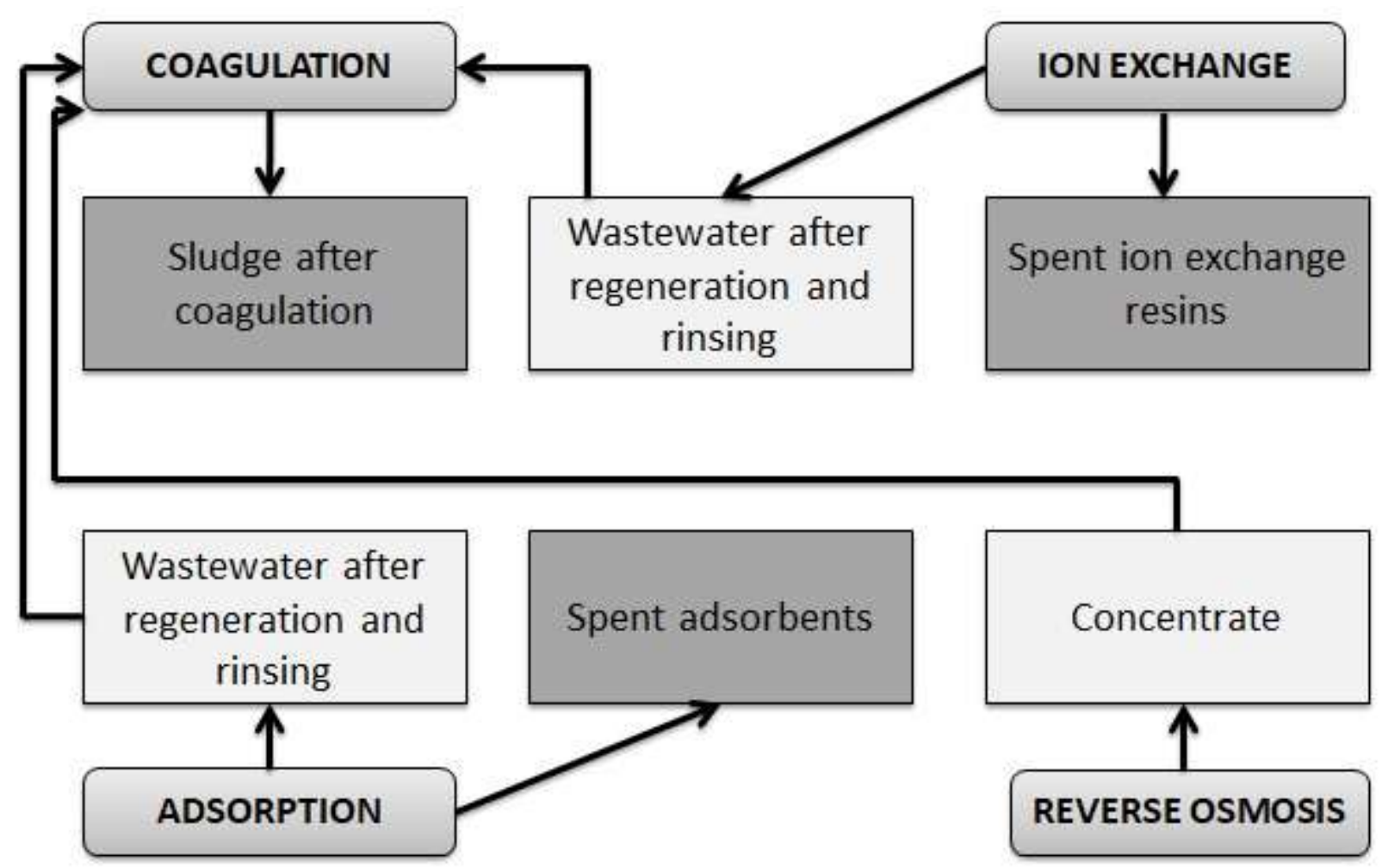

Figure 2. Sources and pathways of arsenic-containing wastes in water treatment. 
Liquid arsenic-containing wastes can be treated by coagulation with iron-based coagulants. Arsenic converts to the solid phase. The volume of waste reduces and the toxicity of waste also became lower (from second to fourth hazard class).

The treatment by $\mathrm{Fe}$ (III)-based coagulants and sorbents is very popular because of the transformation of arsenic into the form of practically insoluble compounds and the possibility of achieving high degrees of arsenic removal. The formation of solid waste with a high content of strongly bound arsenic in the form of ferric arsenates is the result of this treatment.

According to (Litynska et al., 2017), iron (III) arsenate and some other arsenates have a much lower solubility in an alkaline environment, that is, it is advisable to store and use these wastes together with compounds that provide an alkaline reaction.

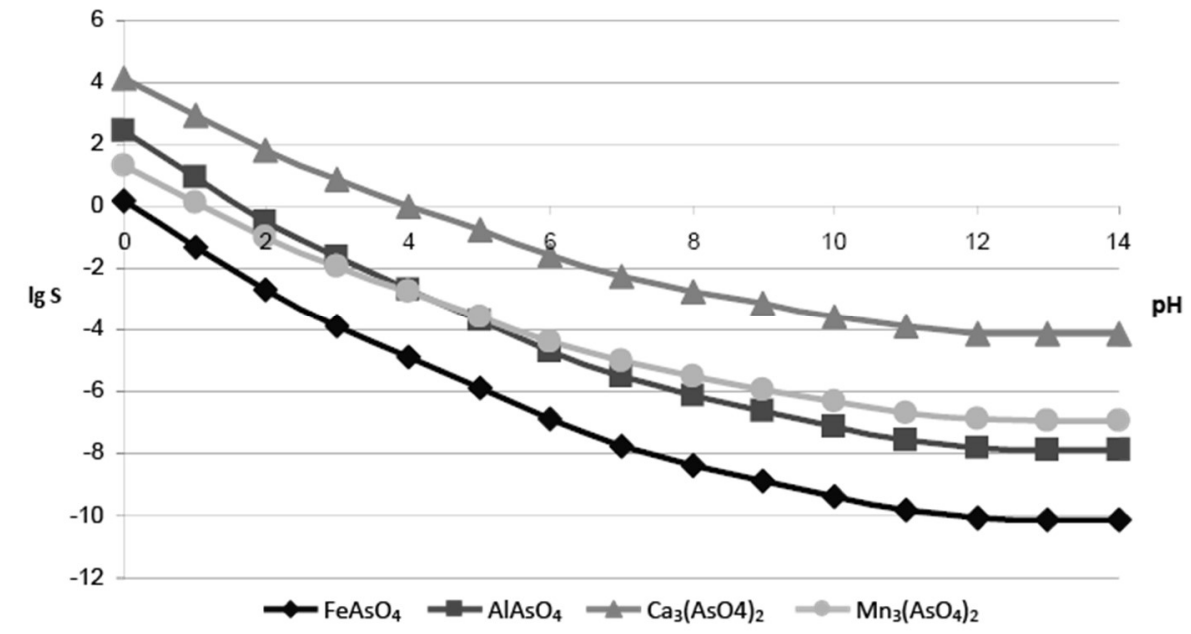

Figure 3. Relation between solubility of some arsenates and pH (Litynska et al., 2017).

Cement is characterized by high $\mathrm{pH}$ values, and the content of arsenic in cement is not normalized, because the human body does not directly contact with cement. Waste containing ferric arsenate can be used in cement production as a source of iron in a small amount or in concrete production for colouring.

\section{Materials and Methods}

\section{IR-spectroscopy}

Fine particle iron (III) oxyhydroxide was used as adsorbent for removal of arsenate. After adsorption material was divided from liquid phase, dried at the room temperature and powdered for IR-spectroscopy. Powdered samples was pressed with $\mathrm{KBr}$ in pellets and analysed by Nicolet Nexus 470.

\section{Cementation}

Iron-based materials (oxides and oxyhydroxides of $\mathrm{Fe}(\mathrm{III})$ ) after adsorption of $\mathrm{As}(\mathrm{V})$ were powdered and mixed with Portland cement M-400, sand and water and poured into cylindrical forms. After 3 days these materials were removed from forms and powdered. Each sample $(20 \mathrm{~g})$ was placed into glass beaker and mixed with $200 \mathrm{~mL}$ of distilled water. After that $\mathrm{pH}$ and arsenic content were determined for each sample after different storage duration.

\section{Arsenic Determination}

For determination of arsenic two reagents were used: working reagent and ascorbic acid solution. Working reagent consisted ammonium molybdate solution $(40 \mathrm{~g} / \mathrm{L})$, sulfuric acid $(2.5 \mathrm{M})$ and solution of antimony potassium tartrate $(3 \mathrm{~g} / \mathrm{L})$. The ratio of these components was 3:10:1. Concentration of ascorbic acid was $18 \mathrm{~g} / \mathrm{L}$ (Litynska et al., 2019).

For preparation of reagents was used Systea Easy Chem methodology for phosphate determination due to significant similarity of phosphates and arsenates. In volumetric flask $(50 \mathrm{~mL})$ $10 \mu \mathrm{g}$ of arsenic (in the form of arsenate solution), $6 \mathrm{~mL}$ of working reagent and $6 \mathrm{~mL}$ of ascorbic acid solution were poured and this mixture was diluted to $50 \mathrm{~mL}$. Blank solution contained the same 
components, but without arsenate. Mixtures were heated at the temperature $60{ }^{\circ} \mathrm{C}$ during 5 minutes for increasing of colour intensity (Litynska et al., 2019). Optical density (A) was measured in $2 \mathrm{~cm}$ glass cuvette by spectrophotometer Hach DR 2800.

\section{$X$-ray Diffraction}

Samples after cementation with adsorbents were powdered and used for X-ray analysis (XRD) by Rigaku Ultima IV.

\section{Results and Discussion}

Correlation between IR-spectrums of Fe(III) oxyhydroxide samples before and after adsorption was about $32 \%$. So adsorption processes took place. According to the Figure 4, iron-based adsorbents removed arsenate-ions in the form of iron arsenates.

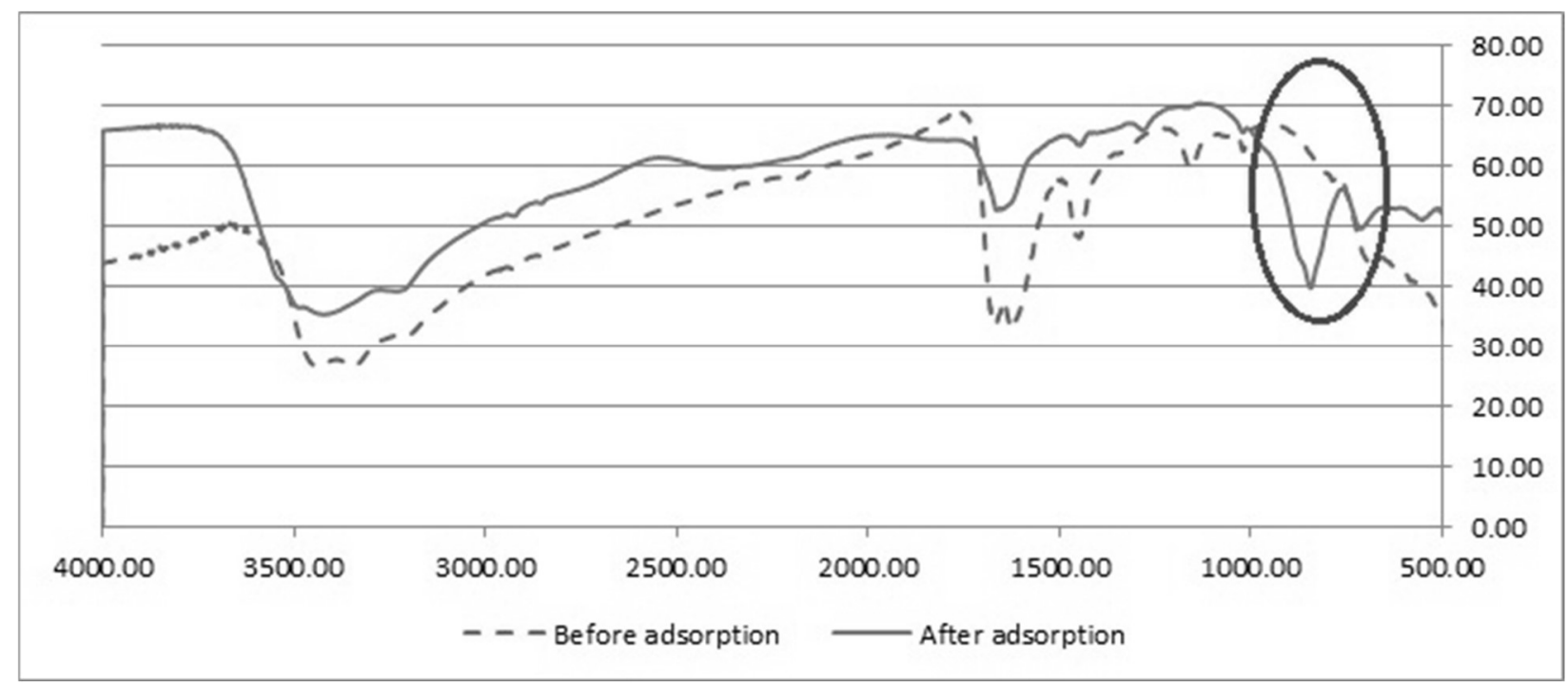

Figure 4. IR-spectrums of Fe(III) oxyhydroxide samples before and after adsorption.

In the both spectrums there were intense bands of various water vibrations $(3500,2030,1640$ and $700-400 \mathrm{~cm}^{-1}$ ). Spectrum of arsenic-containing sample demonstrated two intense bands (716 and $846 \mathrm{~cm}^{-1}$ ), which were typical for arsenates. A similar spectrum was characteristic for salts with an inorganic anion and a high content of sorbed and / or hydrated water.

There were obtained 5 samples by cementation: Blank (without adsorbent); Slow (with suspended $\mathrm{Fe}$ (III) oxyhydroxide and low arsenic content); SHigh (with suspended Fe(III) oxyhydroxide and high arsenic content); Plow (with powdered Fe(III) oxide and low arsenic content) and PHigh (with powdered Fe(III) oxide and high arsenic content).

Figure 5 demonstrated XRD-spectrum of concrete sample. This sample contained iron (III) oxide with adsorbed arsenate-ions. Colour of the sample (PHigh) had some difference from the sample without adsorbent (Blank). Blank sample was light grey and PHigh sample had light salmon colour.

So, this sample contained $\mathrm{SiO}_{2}$ (from sand), $\mathrm{CaSiO}_{3}$ (from Portland cement) and $\mathrm{Fe}_{2} \mathrm{O}_{3}$ (from adsorbent). Arsenic content was too low for visibility at this spectrum.

Table 1 gave information about leaching of arsenates from concrete samples by distilled water. Initial $\mathrm{pH}$ of distilled water was 5.92 .

Arsenic content in samples was calculated from the difference between arsenic concentrations in liquid phase before and after adsorption. Absorbed arsenic as the component of spent adsorbent was added to the mixture, so all arsenic in concrete was from spent adsorbent.

According to the table 1, all concrete samples provoked quick significant increasing of water pH. $\mathrm{pH}$ increased by 4.84-5.06 in just 30 minutes. After 7 days of leaching arsenic was not determined in leachate. So, utilization of arsenic-containing adsorbents in the form of concrete products was safe in case of arsenic content from 53.3-142.2 $\mu \mathrm{g} / \mathrm{g}$. 


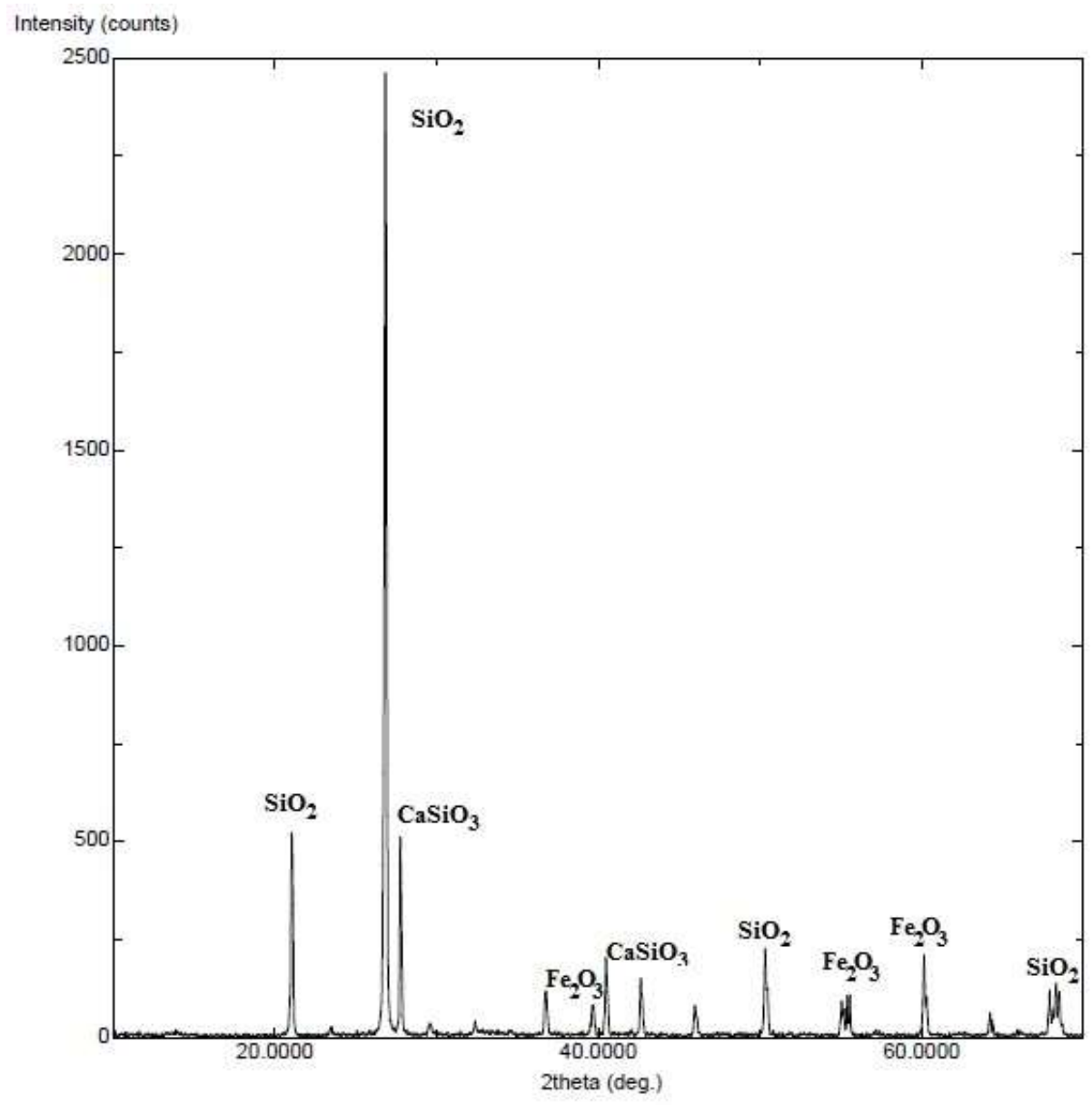

Figure 5. XRD spectrum of sorbent-containing concrete.

Table 1. Leaching from concrete samples with different arsenic content

\begin{tabular}{|c|c|c|c|c|c|c|c|}
\hline \multirow[t]{2}{*}{ Sample } & \multicolumn{5}{|c|}{ Leaching time } & \multirow{2}{*}{$\begin{array}{c}\text { Arsenic } \\
\text { content in } \\
\text { water }\end{array}$} & \multirow{2}{*}{$\begin{array}{c}\text { Arsenic } \\
\text { content in } \\
\text { sample, } \\
\mu \mathrm{g} / \mathrm{g}\end{array}$} \\
\hline & $30 \mathrm{~min}$ & 1 hour & 2 hour & 3 days & 7 days & & \\
\hline Blank & 10.76 & 10.81 & 10.95 & 11.11 & 11.60 & 0 & 0 \\
\hline SLow & 10.89 & 11.00 & 11.00 & 11.15 & 11.50 & 0 & 53.5 \\
\hline SHigh & 10.90 & 10.96 & 10.92 & 11.35 & 11.44 & 0 & 142.2 \\
\hline PLow & 10.92 & 11.00 & 10.93 & 11.32 & 11.54 & 0 & 53.3 \\
\hline PHigh & 10.98 & 11.08 & 11.02 & 11.29 & 11.55 & 0 & 106.7 \\
\hline
\end{tabular}

\section{Conclusions}

As a result of the purification of different natural and wastewaters, numerous arsenic-containing wastes are obtained, which can be conditionally divided into two groups - solid (coagulation sediment, spent adsorbents) and liquid (solutions for regeneration of ion exchange resins and sorbents, concentrates from reverse osmosis).

Liquid arsenic-containing wastes can be treated by coagulation with iron-based coagulants. Arsenic converts to the solid phase. The volume of waste reduces and the toxicity of waste also became lower (from second to fourth hazard class).

The treatment by $\mathrm{Fe}$ (III)-based coagulants and sorbents is very popular because of the transformation of arsenic into the form of practically insoluble compounds and the possibility of 
achieving high degrees of arsenic removal. The formation of solid waste with a high content of strongly bound arsenic in the form of ferric arsenates is the result of this treatment.

Iron (III) arsenate and some other arsenates have a much lower solubility in an alkaline environment, that is, it is advisable to store and use these wastes together with compounds that provide an alkaline reaction.

Cement is characterized by high $\mathrm{pH}$ values, and the content of arsenic in cement is not normalized, because the human body does not directly contact with cement. Waste containing ferric arsenate can be used in cement production as a source of iron in a small amount or in concrete production for colouring.

Concrete sample with powdered $\mathrm{Fe}(\mathrm{III})$ oxide (after adsorption of arsenate) contained $\mathrm{SiO}_{2}$ (from sand), $\mathrm{CaSiO}_{3}$ (from Portland cement) and $\mathrm{Fe}_{2} \mathrm{O}_{3}$ (from adsorbent). Arsenic content was too low for visibility at this spectrum. Colour of the sample had some difference from the sample without adsorbent. Blank concrete sample was light grey and sample with adsorbent had light salmon colour. So, this additive had perspectives in colouring of concrete products.

During storage in distilled water all concrete samples provoked quick significant increasing of water $\mathrm{pH}$. $\mathrm{pH}$ increased by 4.84-5.06 in just 30 minutes. After 7 days of leaching arsenic was not determined in leachate. So, utilization of arsenic-containing adsorbents in the form of concrete products was safe in case of arsenic content from 53.3-142.2 $\mu \mathrm{g} / \mathrm{g}$.

But arsenic leaching may take place in long term perspective due to carbonization processes and $\mathrm{pH}$ decreasing. So, it is necessary to do experiments with these concrete samples after long-term storage (few months or years).

Also utilization of arsenic-containing adsorbents in the form of concrete can have perspectives in the context of concrete biostability for usage in biocorrosive environment. These experiments are also very long-time, but may take place in future.

\section{МЫШЬЯКСОДЕРЖАЩИЕ ОТХОДЫ ВОДООЧИСТКИ: ВОЗМОЖНЫЕ ПУТИ УТИЛИЗАЦИИ}

\section{М. Литинская, А. Гусак, Н. Толстопалова, И. Астрелин}

Национальный технический университет Украины «Киевский политехнический институт имени Игоря Сикорского», Киев, Украина, m.litynska-2017@kpi.ua

Арсенат железа (III) и некоторые другие арсенать имеют гораздо более низкую растворимость в щуелочной среде, то есть желательно хранить и использовать эти отходы вместе с соединениями, обеспечиваюшими щелочную реакиию. Цемент характеризуется высокими значениями $\mathrm{pH}$, а содержание мышьяка в цементе не нормируется, поскольку организм человека напрямую не контактирует с иементом. Результаты экспериментов доказали, что утилизация мышьяксодержащих адсорбентов в виде изементных изделий является безопасным при содержании мышьяка 53,3-142,2 мкг/2 и имеет перспективы в окрашивании бетонных изделий.

Ключевые слова: арсенат; бетон; соединения мышьяка; утилизация адсорбентов; иемент. 


\title{
АРСЕНОВМІСНІ ВІДХОДИ ВОДООЧИЩЕННЯ: МОЖЛИВІ ШЛЯХИ УТИЛІЗАЦІї
}

\author{
М. Літинська, А. Гусак, Н. Толстопалова, І. Астрелін \\ Національний технічний університет України «Київський політехнічний інститут імені \\ Ігоря Сікорського», m.litynska-2017@kpi.ua
}

\begin{abstract}
Більшість сполук арсену є високотоксичними, в результаті чого потрапляння цих речовин в людський організм разом з водою чи їжею або тривалий контакт зі шкірою призводить до численних проблем зі здоров'ям (гіперкератоз, меланоз, ракові захворювання, ендокринні розлади, генотоксичні ефректи тощо), щчо робить видалення сполук арсену дуже важливим процесом у водоочищенні. Природні води багатьох краӥн та стічні води деяких підприємств містять великі концентрації сполук арсену, які в результаті процесів водоочищення переходять у різноманітні тверді та рідкі відходи (коагуляційні илами, відпрацьовані адсорбенти, регенераційні розчини, концентрат зі стадії зворотного осмосу тощо). Зазвичай сполуки арсену іммобілізуються у вигляді нерозчинних сполук феруму в результаті перебігу коагулячії чи ряду інших прочесів водоочищення. Ферум (III) арсенат та деякі інші арсенати мають набагато нижчу розчинність в лужному середовищі, тобто бажано зберігати і використовувати иі відходи разом зі сполуками, щуо забезпечують лужну реакиію. Одним з таких матеріалів є цемент, який характеризується високими значеннями pH, а вміст арсену в иементі не нормується, оскільки організм людини безпосередньо не контактує з ичементом. Результати експериментів довели, щзо утилізація забруднених арсеном адсорбентів у вигляді иементних виробів є відносно безпечною за вмісту арсену 53,3142,2 мкг/2, оскільки вимивання арсенатів не відбулося навіть за 7 днів. Відпрацьовані залізовмісні адсорбенти мають перспективи як забарвлюючі добавки бетонних виробів, оскільки навіть незначна кількість $\mathrm{Fe}_{2} \mathrm{O}_{3}$ надає готовим бетонним виробам приємний лососевий відтінок. Різні сполуки феруму (III) можуть надавати спектр відтінків бетонним виробам (жовтуваті, охристі, коричневі, лососеві тощо), щуо є перспективним в контексті виробництва тротуарної плитки, будівельних матеріалів та в деяких інших галузях.
\end{abstract}

Ключові слова: арсенат; бетон; сполуки арсену; утилізація адсорбентів; цемент.

\section{References}

Amini et al., Statistical Modeling of Global Geogenic Arsenic Contamination in Groundwater. Environ. Sci. Technol. 2008, 42, 3669-3675.

Berg, M. Arsenic contamination of groundwater and drinking water in the Red river delta, Vietnam: Geochemical investigations and mitigation measures, dis. dok. natur. Zurich, Schweiz. 2007.

He, J., \& Charlet, L. A review of arsenic presence in China drinking water. Journal of Hydrology. 2013. 492, 79-88.

Litynska, M., Tolstopalova, N. and Astrelin, I. Neutralization of arsenic pollutants, contained in natural waters: The theoretical analysis of solubility of some arsenates and optimization of the processes. J. Water Environ. Nanotechnol. 2017. 2(1), 1-8. DOI:10.7508/jwent.2017.01.001

Litynska M., Antoniuk R. Influence of temperature on analytical signal in photometric determination of arsenate-ions. Innovative materials and technologies: materials of reports of the International scientific and technical conference of young scientists. 9-10 January, Minsk 2019. P. 169-171.

Magellan K, Barral-Fraga L, Rovira M, et al. Behvioural and physical effects of arsenic exposure in fish are aggravated by aquatic algae. Aquatic Toxicol. 2014. 156, 16-24.

Mosaferi, M., Yunesian, M., Mesdaghinia, A., Nadim, A., Nasseri, S., \& Mahvi, a H., 2003. Arsenic occurrence in drinking water of I.R. of Iran - the case of Kurdistan province. Fate of Arsenic 
in the Environment, Proceedings of the BUET-UNU International Symposium, 5-6 February 2003, Dhaka, Bangladesh. - P. 1-6.

Steinmaus, C. M., Ferreccio, C., Romo, J. A., Yuan, Y., \& Smith, A. H. NIH Public Access. 2014. 22(4), 1-16. 